\title{
IQTISHODUNA
}

IQTISHODUNA: Jurnal Ekonomi Islam

E-ISSN: 2443-0056, P-ISSN: 2252-5661

Accredited Sinta 2 Number 148/M/KPT/2020

Volume 9 Issue 2, October 2020 | Page: 151-166

DOI: doi.org/10.36835/iqtishoduna.v9i2.526

\section{The Concept Maslahah of Najamuddin Al-Tufi and It's Relevance of Sharia Business}

\author{
Munadi', Budi Iswanto ${ }^{2}$ \\ 1, 2 Department of Islamic Economic, Faculty of Islamic Economics and Business, Institut Agama \\ Islam Sultan Muhammad Syafiuddin Sambas, Jl. Raya Sejangkung Kawasan Pendidikan Tinggi \\ No. 126 Sebayan Sambas 79460 Kalimantan Barat, Indonesia. \\ e-mail. ${ }^{1}$ munadi16176@gmail.com ${ }^{2}$ isawantob96@gmail.com
}

\begin{abstract}
Al-Tufi is one of the maslahah figures. al-Tufi defines maslahah based on two things, in urf and shar'i, while in urf is a factor that leads to goodness and benefits. Like trading that brings profit. While according to shar'i maslahah is a causal factor that leads to the intention of lawmakers in matters of worship, as well as customs. The rationalization effort based on the spirit of shar'i arguments in its dialectical form delivered Al-Tufi's thoughts towards the reactualization of Islamic law in the field of muamalah which was more applicable and found a significant momentum. Considering the need for renewal of Islamic law based on a public benefit is more pronounced in this modern era especially in business, with this Al-Tufi method, Sharia business law will be dynamic and progressive again. Is not the Islamic Sharia down to earth intending to achieve human maslahah.
\end{abstract}

Keywords: maslahah, muamalah, sharia business

Abstrak: Al-Tufi merupakan salah satu tokoh maslahah. al-Tufi mengartikan maslahah berdasarkan dua hal, yaitu urf dan syar'i, sedangkan di urf adalah faktor yang mengarah pada kebaikan dan manfaat. Seperti perdagangan yang mendatangkan keuntungan. Sedangkan menurut syar'i maslahah merupakan faktor penyebab yang mengarah pada niat pembuat undang-undang dalam urusan ibadah, juga adat istiadat. Upaya rasionalisasi yang dilandasi semangat dalil syar'i dalam bentuk dialektiknya menyampaikan pemikiran Al-Tufi menuju realisasi kembali hukum Islam di bidang muamalah yang lebih aplikatif dan menemukan momentum yang signifikan. Mengingat kebutuhan pembaharuan hukum Islam yang berbasis kemaslahatan masyarakat semakin terasa di era modern ini khususnya dalam berbisnis, dengan metode Al-Tufi ini maka hukum bisnis syariah akan dinamis dan progresif kembali. Bukankah Syariah Islam membumi dengan tujuan mencapai maslahah manusia.

Kata kunci: Maslahah, Muamalah, bisnis syariah

\section{Introduction}

Al-Thufi Trying to get out of the bondage of the nash (Bayani) towards the rationalist-objectivismoriented burhani. This is what is then called the shifting paradigm.

\author{
Based on the hadith \\ ضرار 1 seems to be a pile of forces \\ 1The full text of this hadith reads عن بن \\ أبي سعيد سعد بن سنان الخدري رضي الله عنه أن رسول الله \\ means: \\ From Abu Sa'i d, Sa'ad ibn Sina n Al Khudri \\ Allaah 'anhu, in fact the Prophet \\ sallallaahu'alaihi wasallam said: "You must \\ not do acts (mud\} arat) that harm yourself
}


capable of changing mindsets that can be said to be radical and liberal. This liberal and radical character then made Al-Thufi accused as adherents of mu'tazilah. It would not be an exaggeration to say that Al-Thufi has sublimated the bayani ${ }^{2}$ and bpppurhani traditions as well as a frame for finding benefits. Thus Al-Thufi clearly distinguishes which teachings are technical and which teachings are objective. Because of the purpose, it takes precedence over the technical nature. While benefit is the goal of Islamic law. So when there is a contradiction between the texts and ijma 'on the one hand and the problem of the

and others". Mother' Abd Allah Muhammad bin Yazid Ibn Majah alQawini, Sunan Ibn Majah, Dar al-Fikr, Beirut, t.th, Juz VI, p. 88.

${ }^{2}$ According to Mohammad Abid alJabiri the epistemology of Islam is divided into 3 types. First is Babani epistemology, second is Burhani epistemology, third is Irfan epistemology. Bayani is an epistemology that tries to understand and analyze texts in order to get the meaning that is pronounced lafaz. In other words this epistemology wants to bring out the meaning of zahir and 'pilgrims who are zahir too. It is expressed through texts by looking at the relationship between lafaz and meaning. The Burhani epistemology is an epistemology obtained from the senses derived from the experiments of the laws of logic. He makes the text and reality and the relationship between them as a source of study. While the epistemology 'Irfani relies more on instruments of inner experience in wear, sal, and intuition. This epistemology is used by the Kasyafi school of thought. Muhammad Abed Al-Jabiri, Bunyah alqAql al-'Arabi, Beirut: al-Markaz al-Tsaqafi al-Arabi, 1991, p. 245. other side, then al-Tufi puts the mashlahah over the texts and ijma'.

$$
\text { More than that }
$$

paradigmatically the statement تقديم seems to be a trademark that also confirms the position of al-Tufi in favor of the maslahah. At the same time substantially relying on the hadith $\gamma$ ضرار و لا ضرار in the form of the spirit of this tradition reflects that alTufi still exalts the text as its basis and not abandon it let alone eliminate it. The methodological framework used in solving this problem is takhsis and tabyin, not tarjih, nasakh or istisna '. Takhsis here is understood in the context of turning from universal texts to more particular texts. In such circumstances it is closer to the inauguration and elimination effort.

Furthermore, the rationalization efforts based on the spirit of the hadith above in its dialectical form deliver the thought of al-Tufi towards the reactualization of Islamic law in the field of muamalah which is more applicable and finds a significant momentum. Considering the need for renewal of Islamic law based on public benefit is more pronounced in this modern era especially in business, with this al-Tufi method, Sharia business law will be dynamic and progressive again. Is not the Islamic Sharia down to earth with the aim of achieving human maslahah. Are not the rules of fiqh proposal that were compiled based on the purpose of maintaining the maslahah. 
2. Overview of al-Tufi and his opinion about Maslashah

A short biography of al-Tufi

Actually the word al-Tufi is an adjective that is related to the word Tawfa which is called the name of a village near Baghdad in Iraq now. So al-Tufi is a person who came from Tawfa. Naj al-Tufi which means "Religious Star", is a nickname or title (laqab) given to the writer by his worshipers. Thus, if our author's popular name is Najm al-Tufi where his real name is Sulaiman Ibn 'Abd al-Qawiyy Ibn' Abd al-Karim Ibn Sa'id al-Tufi alShar Shary al-Hanbaly was born around $675 \mathrm{AH}$ and died the world in Palestine around $716 \mathrm{H}$ (1316 AD) another source said that al-Tufi was born in $657 \mathrm{AH}^{3}$

Little information that can be known about al-Tufi's life has been researched and published by Mustafa Zayd. ${ }^{4}$ It seems that the important thing is his ability to free himself, to a noteworthy level, from the influence of traditional schools of law, especially from their criticism and hatred of critical reason and neglect of the universal principles of the Koran, such as protection of benefit human. However, he was born and

\footnotetext{
${ }^{3}$ Mustafa Zayd, al-Mas\}lah\}ah fi alTasyri>' al-Isla>mi al-Di>n al-T\}ufi, ed ${ }^{2}$, Kairo, Da>r al-Fikr al-'Arabi, 1384 H/1964 M, 6 .

${ }^{4}$ Ibid., 63-91.
}

educated as a Muslim of the Hambali school whose followers are especially famous for his strong aversion to reason and his animosity towards independent free thinkers.

The conspiracy against alTufi by ulama or jurists appears to have occurred because his respect for reason was seen as challenging the legitimacy, authority, truth or authenticity of the basic assumptions of their schools of law, especially their assumptions relating to the Sunnah of the Prophet, therefore, the oppression and torture of the mind and its defenders, since the days of alMutawakkil (d. 247 H / 861 AD), seems to have made it possible for scholars and schools of law to force their opinions to be followed by sheer force. which, respectively, was given to them, apparently in return for their cooperation with the authorities, especially for their de facto justification of the power struggle. Indeed, some Muslim fiction that is hostile to the usurpation of power by the Umayyads and 'Abbasids, or those who defend the rules of reason or justice, which is in accordance with the principle of universality of the Koran, has been branded, via traditions, as adherents of heresy and enemies. enemy of Islam and may be sentenced to death.

But al-Tufi was formally accused by the ulema as followers of 
one of the frictions, the Shi'ah and then stated to the political authorities that he did not recognize the legitimacy of the power they seized and also the struggle for political power that he did not recognize the legitimacy of the power they seized and also the struggle for power of dynasties or conquerors of the past, and only follows the legitimacy of the rule of the fourth Caliph and his descendants. This accusation appears to have been intended by his enemies to show that he did not recognize their own laws or religious justifications for the legitimacy of the ruling regime and did not accept the validity of the sources on which the justifications were taken, namely the Sunnah of the Prophet.

\section{Al-Tufi's Education and Work}

al-Tufi is a well-known figure as a lover of knowledge. Aside from being famous for being smart, alTufi is also known for his rote memorization. He proved his love for science with his adventures in learning various scientific disciplines in various places from the famous scholars in his day. Among the fields of science he concentrated on were commentaries, hadith, fiqh, mantiq, literature, theology, and so forth. Whereas the places he had visited in his scientific adventures were Sarsari, Bahgdad and Damascus, who at that time were known as prominent ulama. ${ }^{5}$

At a young age, al-Tufi learned the slander of his birth, studying and memorizing the book of fiqh Mukhatasar al-Khiraqi by Umar Husein bin Abdullah bin Ahmad al-Khiraqi and al-Tufi also studied the book of nahu al-Luma 'by Abu al-Fathi Usman bin Jani. ${ }^{6}$ After that he often went to Sarsar to study jurisprudence at Shaykh alDin bin Muhammad al-Sarsari, one of the faqih of the Hanbali school known as Ibn al-Bauqi.

After that he continued his scientific adventure to Baghdad in $691 \mathrm{AH}$ and succeeded in memorizing the book of fiqh alMuharrar by Imam Majiduddin "Abd Salam Abdullah Ibn Taimiyyah, then discussed it with Shaykh Taqiu al-Din al-Zarirani. He studied Arabic with Muhammad bin Husen al-Musali, while the study of Jurisprudence he studied with his teacher al-Nasir al-Faruqi and other scholars. The science of hadith he studied with Ibn alTabba'i and other scholars, such as al-Rashid Ibn Qasim, al-Hafiz alHaramy, Abu Bakr al-Falasany in Madrasah al-Mustansariyyah and others. ${ }^{7}$

From Baghdad, al-Tufi headed for Damascus in $704 \mathrm{AH}$, where this intellectual struggle with

${ }^{5}$ Ibid., 72.

6Ibid., 70 .

${ }^{7}$ Ibid., 70-71. 
experts took place intensely. Especially in the experts on interpretation, the science of hadith, fiqh from the Hanbali school, including discourse struggles here is Sheikh Ibn Taymiyah. ${ }^{8}$

From Damascus, al-Tufi then swerved towards Cairo. In this place, liberal thinking seems like what happened before. Because of this liberalism in his thinking, history records that al-Tufi was in prison for several days because he was punished by ta'zir by the ruler of Qadi Saad al-Din al-Hadisi. ${ }^{9}$ alTufi as a Muslim, he made the hajj in $714 \mathrm{H}$, then hajj again in $715 \mathrm{H}$. While the end of his adventure, alTufi returned to Sham and lived in Palestine until he died in 716 H. ${ }^{10}$

It is not strange if al-Tufi as explained above that he is known to master various fields of science. So from here it is natural from the results of his study, al-Tufi wrote many of his works namely: ${ }^{11}$

a. Al-Tufi's work in the field of alQuran and Hadith

1) Al-Iksir fi qawa'id al-Tafsir.

2) Al-Isyarat al-Ilahiyyah 'Ala alMabahits al-Usuliyah.

3) Idhah al-Bayan 'an ma'na umm al-Qur'an.

4) Al-Mukhtasar al-Mu'alin.

5) Majmu' tafsir surah Kaf wa alNaba'.

\footnotetext{
${ }^{8}$ Ibid., 72.

9Ibid., 74 .

10Ibid., 68.

${ }^{11}$ Ibid., 105-106.
}

6) Jada al-Qur'an.

7) Bughiyah al-Wasil 'ila ma' rifah al-Fawasil.

8) Daf'al-Ta'arud 'amma yuhimu al-Tanaquza fi al-Kitab wa-alsunnati.

9) Syarh al-Arba'in alNawawiyah.

10) Mukhtasar al-Tirmizi.

b. Al-Tufi's work in the field of Fiqh and Proposed Fiqh

1) Bughiyyah al-Sa'il fi ummahat al-Masa'il (usul al-Din).

2) Qudwah al-Muhtadin ila maqasid al-Din.

3) Khilal al-Aqdi fi ahkam alMu'taqid.

4) Al-Intiserat al-Islamiyyah fi daf'syubhati al-Nasraniyyah.

5) Dar' al-Qaul al-Qabih fi alAtahsin wa al-Taqbih.

6) Al-Bahir fi ahkam al-Batin aw al-Zahir.

7) Radda 'ala al-Ittihadiyyah.

8) Ta'liq ala al-Anajil wa tanaquziha.

9) Qasidah fi al-Aqidah wa syarhiha

10) Al-Azab al-Wasib 'ala arwa $>h$ al-Nawasib

11) Mukhtashar al-Raud\}ah (kitab usul al-Fiqh).

12) Syarah mukhtasar al-Rauzah al-Qidamiyyah tiga jilid.

13) Mukhtas\}ar al-Khasil.

14) Mukhtashor al-Makhsul.

15) Mi'raj al-Wus\}ul ila ilm alUsul.

16) Al-Dzari'ah ila ma'rifah asrar al-Syari'ah.

17) Al-Riyadl al-Nawadzir fi alAsybah wa al-Nadza'ir. 
18) Al-Qawa'id al-Kubra.

19) Al-Qawa'id al-Sughra.

20) Syarh mukhtashor al-Kharqy.

21) Muqaddimah fi ilm alFara'idh.

22) Syarah mukhtashor alTibrizy (fi fiqh al-Syafi').

c. Al-Tufi's works in linguistics, literature and other materials

1) Al-Su'aqah al-Ghadzabiyyah fi al-Raddy ala al-Munkiry alArabiyyah.

2) Al-Risalah al-Ulwiyah fi alQawa'id al-Arabiyyah.

3) Ghaflah al-Mujtaj fi al-m alHaqiqah wa al-Majaz.

4) Tukhfah ahl al-Adab fi ma'rifah lisan al-Arab.

5) Al-Rahiq al-Salsal fi al-Adab al-Musalsal.

6) Mawa'id al-Khais fi syi'ri imri'y al-Qays.

7) Al-Syi'ar al-Mukhtar ala mukhtar al-Isy'ar.

8) Syarh muqamat al-Khariry (tiga jilid).

9) Izalah al-Inkad fi mas'alah kadin.

10) Daf' al-Malam fi manthiq waAl-kalam.

In the last work of al-Tufi entitled Daf 'al-Malam fi Manthiq wa al-Kalam (Rebuttal to Supporters of Logic and Systematic Theology) which asserts that it makes sense to defend rational principles and theology, and defend against early Muslims upholding, especially the Mu'tazilites. ${ }^{12}$

\footnotetext{
12Ibid., 91.
}

\section{The Concept of Maslahah Najm al- Din Thufi and Its Relevance to Sharia Business Understanding Maslahah}

In order to understand correctly about maslahah, it is necessary to pay attention to the development of its meaning, both etymologically and terminologically. The etymological meaning of maslahah has two very different meanings. ${ }^{13}$ First, maslahah has the same meaning as the benefits both in meaning and in the use of lafaz. Maslahah is sometimes in the form of mashar or الصلوح or maslahah is a form

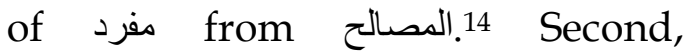
etymologically used maslahah for actions that contain benefits, in majaz mursal, such as trading maslahah, seeking knowledge\}\}.

\footnotetext{
${ }^{13}$ Husein Hamid Hasan,
}

Nazariyyah al-Maslahah fi al-fiqh al-Islami, Cairo, Dar al-Nahdhah al-abiArabiyyah, 1991.5

مصدر ميم is الصلاح means المصلحة 14 from lafaz صلح يصلح. The إستصلاح is the opposite of إستفساد بـ See Jamaluddin Muhammad bin Maukarram al-Ansari, Lisan al-'Arab, Cairo, Dar al-Misriyyah, t.t., juz. 3, p. 304. While in al-Munjid it is stated that صلح بصلح means loss of damage. When it is said صلحت حال فلان means it has lost its damage. See Louis Makluf, al-Munjid fi alLughah wa al-lamAlam, Beirut, Dar alMasriq, 1986, p. 432. Meanwhile according to al-Munjid, المصلحة, etymologically comes from Arabic language which is constructed

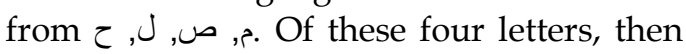

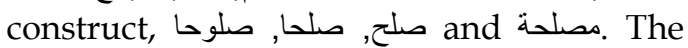
word means kindness, justice, piety and honesty. See Fuad Irfan, Munjid al-Tullah, Beirut, Dar al-Fikr, t.t., p. 479. 
This means that trading and seeking knowledge can bring about maslahah. ${ }^{15}$

According to 'Abdillah $\mathrm{M}$. Husayn al-'Amiri, the word maslahah from the word الصلاح (goodness, usefulness, validity and truth), which means that something is in perfect form (hay'ah kamilah) in accordance with the goals or objectives referred to, as the pen is in its most appropriate (salih) shape when used for cutting. ${ }^{16}$

While etymologically the problem, to dissect this definition, there are two figures that the author quotes in this paper.

a. Al-Ghazali

$\mathrm{He}$ is a thinker from the Shafi'iyyah formulation of maslahah as "an effort to take advantage and reject harm in order to maintain the goals of shari'ah. ${ }^{17}$

b. Al-Tufi

Al-Tufi defines maslahah based on two things, namely in urf and shar'i, while in urf is السبب المؤدي

\footnotetext{
${ }^{15}$ Hafiny ibn Nafis, Qawaid alLughah al-rArabiyyah $\mathrm{Li}$ al-Talamidz alMadaris al-Sanawiyah, Surabaya: alHidayah, t.t., p. 124-127.

${ }^{16}$ Abdillah M. Al-Husayn al-'Amiri, al-Thufi Feflection of Traditional Muslim Juristic Source of Law and His Views On The Priority of Regard for Human Welfare as The Highest Legal Source or Prinsciple, terj. Abdul Basir, Jakarta: Gaya Media Pratama, 2004, p. 101

${ }^{17}$ Al-Ghazali, al-Mustashfa fi Ilm alUsul, Volume I, Beirut: Dar al-Kutub alIIlmiyyah, 1983, p. 286.
}

إلي صلاح و النفع: is a factor that brings benefits to the good and benefits. Like trading that brings profit. While according to syat'i maslahah namely: السبب المؤدي إلي مقصود الشارع عبادة أو عادة19 causative factors that lead to the intention of law makers in the origin of matters of worship or customs (habits). Maslahah is divided into two: described by lawmakers for their own sake. As beautiful as intended by lawmakers for the benefit of His creatures and the regulation of their affairs as is customary.

In another source, it is stated that in al-Tufi's view the maslahah is also defined as taking advantage and resisting danger. ${ }^{20}$ As for what is desired by the benefits here according to Imama al-Razi is pleasure and desired damage is pain. He further said that: "The problem is nothing but pleasure or everything that delivers to him and damage is nothing but pain or everything that delivers to him. ${ }^{21}$

Starting from a little building formulation masahlah both in terms of etymology and terminology perspective above, can be built or conclusions understanding that

\footnotetext{
${ }^{18}$ Mustafa Zayd, al-Maslahah fi at-Tasyri 'alIslami Najm al-Din al-Thufi, Second edition, Cairo: Dar al-Fikr al-rArabiya, 1384/1964 AD, p. 54. ${ }^{19} \mathrm{Ibid} .$, p. 55.

${ }^{20}$ Abdurrahman al-Kaylani, Qawaid alMaqasid 'inda Imam Syatibi, Damasyq: Dar al-Fikr, 2000, p. 126.

${ }^{21}$ lbid., p. 126.
} 
maslahah which is an instrument or method of operationalizing ijtihad can be digested as a legal determination of a case that is completely lonely and quiet from the provision of texts with and for consideration for the benefit of human life which results in withdrawing benefits and eliminating kemudharatan.

\section{Al-Maslahah As The Peak Purpose Of Sharia}

Protection of human benefit, according to al-Tufi is the main goal of Islam or the main source of its goal (qutb maqsud al-Syar'i). Protection and affirmation of it in legal matters, therefore take precedence over other legal considerations. That is, it has priority over all traditional sources of Muslim schools, including the text of the Koran, the Sunnah or the traditions of the Prophet, or ijma', both from Muslim communities and or experts in the schools of law which actually never happened in history. 22 This view, which seems to rule out the existence of this text, is in conflict with the ulama of fiqh in his time. According to the opinion of the ulama at that time, any form of maslahah must have the support of syara', both through certain texts and through the meanings contained in a number of texts. AlTufi's seemingly liberal view caused

\footnotetext{
${ }^{22}$ Mustafa Zayd, al-Maslahah fi at-Tasyri 'alIslami Najm al-Din al-Thufi, ed ${ }^{2}$, Cairo: Dar al-Fikr al-rArabiya, 1384/1964 AD, p. 6.
}

him to be estranged from the scholars of the fiqh proposal of his time. However, his thoughts about this maslahah were widely studied and analyzed by the scholars of fiqh proposal afterwards and many gave birth to doctors in Islamic studies.

Al-Tufi explains, wherever religious texts or 'ijma', two things which in theory are the strongest source of traditional law, are not in harmony with human benefit, human benefit must be prioritized from both. ${ }^{23}$ This is because human benefit is basically a goal in itself. As a result, his protection becomes the highest legal principle or the most powerful source of law. ${ }^{24}$ Al-Tufi's view of the benefit of humanity is obedient to the conception of maqasid al-tasyri 'which confirms that the law is prescribed to realize and maintain human benefit.

Furthermore, al-Tufi shows the benefit of law or worldly life can be known through natural ways given by God to him, namely by the nature of the experiences of human life itself and by the demands of its own intelligence. This natural way, al-Tufi stated, is the most convincing method of understanding and achieving goals. Therefore, he cautioned, the problem should not be replaced by other dubious methods or sources that might lead to human benefit. Because, something that must be

\footnotetext{
${ }^{23} \mathrm{Ibid}$, . p. 6.

${ }^{24} I b i d$, . p. 6.
} 
followed as an authority, al-Tufi stated, is not the conclusions of the jurists, or their interpretations of "religious texts", but strong evidence of reason and visible propositions. ${ }^{25}$ In other words, the highest law of the benefit of law or worldly life is not "religious texts" or the conclusions of jurists about it but the demands of reason and intelligence in human life itself.

Related to this al-Tufi emphasized: "it cannot be said that religious law (as stipulated by the schools of law) knows better about the benefit of humans, and as such, it should be taken from its sources (as determined by them). Because, we have shown that the protection of human benefit is one of the principles of religious law (religious texts). It is the most powerful and unique principle. Therefore, giving priority to him to achieve benefit." 26

Unlike the benefit of law and human worldly life, al-Tufi allows the benefit of religion and matters of worship to be decided or guided by religious texts.

The notion of al-al-Tufi maslahah is not integrated specifically in the book of fiqh. The idea was born when al-Tufi validated hadith number 32 in the book Arbai'in Nawawi by Yahya Ibn Syarifuddin al-Nawawi. ${ }^{27}$ From

${ }^{25} \mathrm{Ibid}$, p. 43.

${ }^{26}$ Abdillah M. Al-Husayn al-'Amiri, p. 43.

${ }^{27}$ Mustafa Zayd, p. 113. this discussion then gave birth to an idea that could be said to be a radical liberal so that it was not excessive if there were ulama us $\mathrm{ul}$ who wrote about him who considered that al-Tufi was a figure that was rarely encountered even before anyone had even proposed it from among previous thinkers or his time.

The hadith in question is $\gamma$ 28 ضرار و لا ضرار (do not cause harm or damage to others and do not reciprocate a loss with other losses). This hadith is used by al-Tufi as textual evidence (argument) for the existence of mas\} lah\} ah. Thus it can be understood that the above hadith is also used as a paradigm of the style of thinking of al-Tufi both from the theoretical plain and its application.

Al-Tufi's argument does not rely on the hadiths mentioned

\footnotetext{
${ }^{28}$ The above hadith is narrated by Abu Sa'id Ibn Malik Ibn Sinan al-Khudri ra. The quality of the above hadith is hasan which is narrated with the complete chain of transmission (sanad) by Ibn Majah, alDarulqutni, and others, but without mentioning his first narrator (mursal) by Imam Malik Ibn Anas in Muwatta ', from' Amir Ibn Yahya from his father, from the Prophet, by not mentioning the name 'Abu Sa'id Ibn Malik Ibn Sinan al-Khudri ra. there are a number of other transmission routes that are mutually reinforcing. See Malik, Muwatta ', Egypt, Dar Ihya 1-Tsurats al- "rabbi, t.t., II, p. 754. Sunan Ibn Majah, Beirut: Dar al-Fikr, t.t., II, p. 784, Hadith No. 2340.
} 
above, but there are also a number of propositions that indicate the concern of the sharia 'towards the maslahah. The postulates are:

a. The word of God in surah alBaqarah (2): 179.

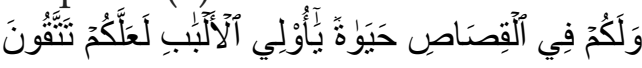

$$
\begin{aligned}
& 1 \vee 9
\end{aligned}
$$

And there is life for you in (the law of) retaliation, $O$ men of understanding, that you may guard yourselves. ${ }^{29}$

b. The word of God in surah alMa'idah (5): 138.

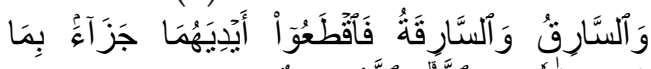

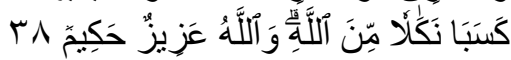
And (as for) the man who steals and the woman who steals, cut off their hands as a punishment for what they have earned, an exemplary punishment from Allah; and Allah is Mighty, Wise. 30

c. The word of God in surah al-Nur (24): 3.

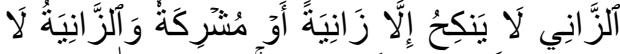

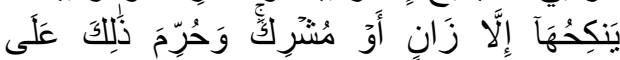

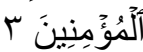

The fornicator shall not marry any but a fornicatress or idolatress, and (as for) the fornicatress, none shall marry her but a fornicator or an idolater; and it is forbidden to the believers. ${ }^{31}$

d. The Prophet's Hadith:

\footnotetext{
${ }^{29}$ Departemen agama Republik Indonesia, al-Quran dan Terjmah, Bandung, PT.Sigma Examedia Arkanleema, 2009, p.27.

${ }^{30}$ Departemen agama Republik Indonesia, p.114.

${ }^{31}$ Departemen agama Republik Indonesia, p.35.
}

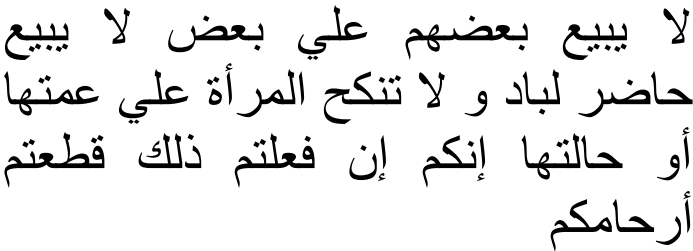

A person should not buy goods that have been offered by others and also guard the city people (traders) to buy his wares by visiting the village farmers and not marrying a woman (at the same time) with his aunt, because if you do that, then you have broken the relationship among you.

\section{The back of Epistemology Maslahah al-Tufi}

In building the maslahah project, al-Tufi relied on four main principles. Each principle is the main framework which is used by al-Tufi as the foundation of his epistemological mind. The four main principles are: 32

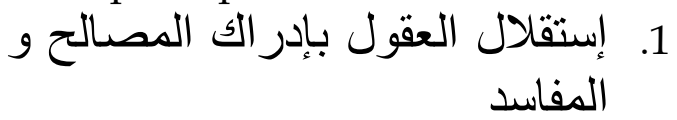

Independence of mind by realizing goodness and damage.

This principle states that human reason can independently find maslahah and mafsadah.

\footnotetext{
${ }^{32}$ Mustafa Zayd, p. 127-132. The principles above are also quoted by Saifuddin Zuhri in his dissertation Maslahah and its implications as a source of Islamic law: Study of the concept of Naj al-Din al-Thufi (Unpublished Dissertation Brief). Yogyakarta, UIN Sunan Kalijaga, 2008, p. 5. and also cited by Munawir Sadzali as alThufi's worshiper in his book, Contextualization of Islamic Teachings, Jakarta: Temprint, 1995, p. 287, also Nasrun Harun quotes in His Book Usul Figh I, Jakarta: Logos Discourse of Science, 1997, p. 1126.
} 
However, the ratio indenpedence in finding maslahah is not in all fields including worship, al-Tufi limits the area of Muamalat and customs. This principle puts forward the role of this ratio clearly different compared to the other usuliyyun who recognize maslahah as a source of law after being shown by law and justified by the text.

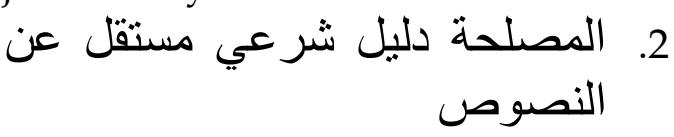

Maslahah is a valid shari'a proposition that is independent of the text.

This principle is a continuation of the above principle, from this expression it can be understood that in the view of atThufi, Maslahah is an independent syar'i proposition. In the sense of Maslahah al-Tufi does not have a dependency on the testimony or confirmation of the text.

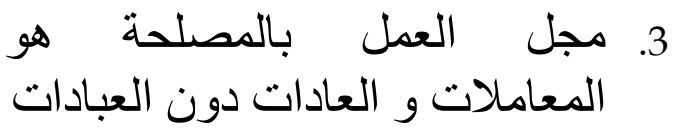

The object of the Maslahah discussion is the Muamalat Field and the kebiasaan adat (customs) not included in the Worship field.

Maslahah as the syar'i proposition the object of the claim is limited to the field of muamalah and 'adah. Thus maslahah according to al-Tufi cannot touch in the area of ritual (worship). In the field of worship according to alTufi, only Allah Almighty has the right. Here reason has no authority. In other words, reason only continues the sustainability aspect of worship itself. While aspects of the change are in the muamalah and adat areas. This is composed by the expression al-Tufi which states as haqqu al-musyari. This means that for al-Tufi human reason is unable to penetrate the secret of the Maslahah behind worship.

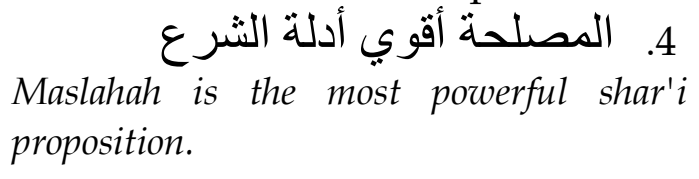
proposition.

Al-Tufi admitted that there were nineteen propositions that could be used as legal methods. But in the eyes of al-Tufi the most powerful of the nineteen are texts and ijma '. But when there is a conflict between maslahah with texts and ijma ',' the path taken by al-Tufi is to win the maslahah. From this reality, it can be understood that as a legal proposition, it is not only functional when the texts and ijma do not confirm it. But it is also functional when the texts and ijma" conflict occur. This indicates that alTufi is more concerned with maslahah compared to other propositions. In such circumstances, Husein Hamid Hasan concluded that the problem for al-Tufi was the most powerful syar'i proposition. ${ }^{33}$

It seems that Husein Hasan Hamid's assessment is not excessive considering that maslahah is an objective in Islamic legal legislation. While the texts and ijma are the

\footnotetext{
${ }^{33}$ Husein Hamid Hasan, Nazariyyah alMaslahah fi al-Figh al-Islamy, Cairo: Dar alNahdhah al-abiArabiyyah, 1991, p. 535.
} 
means to achieving that goal. So if there is a conflict between and nas\} ijma 'on the one hand with the maslahah on the other hand, the maslahah must take precedence because the goal is more important than the means. While the texts and ijma 'are nothing more than a means to an end in itself namely benefit. This reason seems to coincide with what al-Tufi revealed "because maslahah is the goal of a mukallaf in establishing the law, then putting aside the proposition as a means of maslahah (as a goal) becomes urgent because the goal must take precedence over the means.

From this it can be seen that the tendency of al-Tufi to prioritize the maslahah compared to the arguments is very obvious. Thus it can be analyzed that the problem here is to act as the substance of the law itself. Whereas the texts and ijma and other propositions become the role of means to achieve the substance itself.

Al-Tufi's epistemological footing above has its own uniqueness compared to other propositions. For example, for example, with al-Syatibi who indeed from the beginning developed his problem with his istiqra meaning model and his al-Shariah maqashid. As for al-Ghazali who made the mas\} ah\} the ah is still very thick in the shar'i frame. However, al-Tufi here has a different side diametrally when discussing the epistemological backrest, given that in establishing Islamic law, the involvement of reason in establishing law in al-
Tufi's thought gets its portion significantly.

\section{Rules relating to Maslahah}

$$
\text { 1. جلب المصالح و دفع المفاسد }
$$

Reaching benefit and rejecting harm

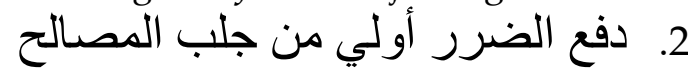

Rejecting harm is more important than achieving benefit

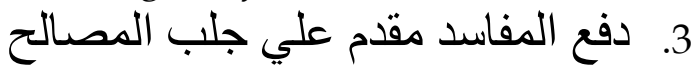

Menolak kerusakan didahulukan daripada meraih kemaslahatan

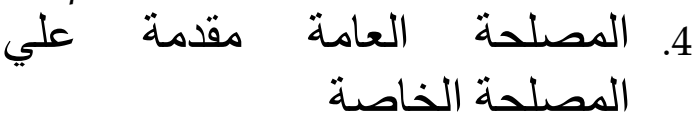

General benefit takes precedence over special benefit

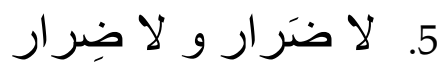

It cannot be made easy and it should be made easy. ${ }^{34}$

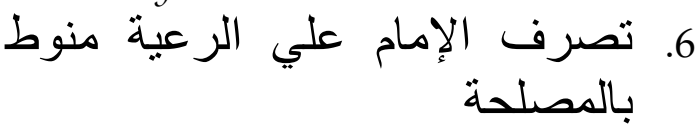

The actions of the Imam (the authority holder) towards the people must follow the benefits. 35

7.
The kemudharatan must be
eliminated. ${ }^{36}$

\footnotetext{
${ }^{34}$ Ahmad al-Nadwi, al-Qawaid alFiqhiyyah, Beirut: Dar al-Qalam, $1420 \mathrm{H}$ / 2000 CE, p. 288. الضرر: there is a benefit for oneself for others to make it easy, الضرر: there is no benefit for oneself and for oneself and for others to make it easy.

${ }^{35}$ Al-Syuyuthi, al-Ashbah wa al-Nazha'ir, tahqiq: Muhammad al-Mu'tashim bi Allah al-Baghdadi, Beirut: Dar al-Kitab al-rArabi, 1978, p. 240.

${ }^{36}$ It is a basic principle, see A.Jazuli, Rules of Islamic Law Solving Practical Problems, Jakarta: Pranada Media, 2000, p. 33. There are several derivative rules from the above basic principles of faith, namely:
} 


\section{Al-Maslahah Najm al-Tufi and Its Relevance to Sharia Business}

The relevance of al-Tufi's maslahah to Sharia business has actually been clearly involved in the epistemological footing, number three, which is used as the foundation of its mega-project maslahah which is clearly stated: مجل العمل بالمصلحة و العادات دون العبادات or the method of operationalization is only Muamalat (including business) not matters of worship. In the matter of worship al-Tufi invited religious texts to guide him.

The existence of al-Maslahah in Sharia business in the Indonesian context is clearly seen in the principles of entering into an agreement. In Sharia contract law, there are several principles that must be based on them, while those principles are the principle of alMaslahah. With the principle of benefit is meant that the contract made by the parties aims to realize the benefit for them and does not cause harm or burden. If in the implementation of the contract there is a change in circumstances that can not be known in advance and bring a fatal loss to the parties concerned so that it is burdensome, then the

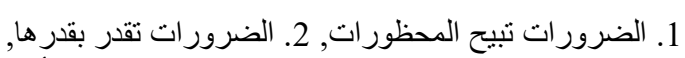
3. الضرر لا يز ال بمثلها, 4. يحتمل الضرر الضرر الخاص لأجل

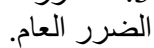

obligations can be changed and adjusted to a reasonable limit. ${ }^{37}$

The doctrine of the burdensome situation, then the obligations can be changed by the judge at the request of the party. ${ }^{38}$ Jurisprudence principles that are not used as a framework for thinking are: الضرر يزال (kemudharatan must be removed).

In reality in Muamalat (Islamic) practitioners in Indonesia, due to Sharia financial institutions, both Sharia Banking, Sharia Insurance, Sharia Leasing, Sharia Venture Capital, Sharia Bonds and so on), are still new and in a state environment that does not (not yet) establish Sharia, then often face difficult situations. In a situation like this, the National Sharia Council of the Indonesian Ulema Council often issues fatwas against the background of dharurah in terms of benefit.

To see how the significance of al-Maslahah as an instrument in establishing the Sharia business, then knowing the principles of fiqh as its medium becomes important. Among the principles of fiqh which reads الضرر يزال this rule aims to resolve the Shariah maqashid by refusing mafsadah or at least alleviating it. So it is not surprising that Ahmad al-Nadwi mentioned that the application of the above rules covered a large field in fiqh

\footnotetext{
${ }^{37}$ Samsul Anwar, Hukum Perjanjian Syariah: Studi Tentang Akad Dalam Muamalat, Jakarta : Rajawali Press, 2007, p. 90.

${ }^{38}$ Samsul Anwar, p. 321.
} 
and could even cover all the existing fiqh material. an example that can be proposed in this matter is the prohibition in the Sharia business of hoarding goods for basic needs of the community because the Sharia business considers that such actions could result in harm to the people. In the ban there is a problem for the community because of the rejection of harm or withdrawal of the benefits of its main purpose to achieve the benefit behind both. But with this example a question can be asked about the hoarding by Bulog. It is important to know that the hoarding by Bulog in order to maintain price stability and guarantee the availability of basic foodstuffs, such as rice, the storage and storage of rice by Bulog can be justified even required even if it contradicts the sound of the hadith "cannot hold property unless a person is persecuted". This is the application of al-Tufi's explanation that wherever religious texts or ijma " are theoretically the most powerful sources of traditional law - out of harmony with human benefit, human benefit must be prioritized from both (religious text and ijma ").

\section{Critical Study of the Epistemology of the Maslahah al-Tufi}

This priority and precedence over Nash is pursued both the passage of qat'i in its sanad and matan or zhanni both. If we look at al-Tufi's explanation with the four principles above, the writer can observe that al-Tufi is actually playing in the level of Usul Fiqh, he presupposes a clash between the texts between or ijma 'on the one hand and the problem on the other hand. The problem is, is it true that there was a clash that he meant. Until now al-Tufi has not revealed a single example of the conflict between maslahah and nash and ijma '. Indeed, al-Tufi in expressing his opinion is more theoretical and in his discussion, al-Tufi seems poor example.

It must also be understood that the theological tendencies espoused by al-Tufi and those who agree with him in terms of the power of reason. According to him, reason has the power and independence in choosing and determining which is independent of the text. By borrowing a new trend of ushu fiqh studies which is correlated with kalam science, it will feel something odd. How is it possible that al-Tufi, who is considered a follower of the Imam Hanbal school, in the knowledge of kalam, is in line with mu'tazilah. Maybe the writer was wrong, but at least the strangely atmospheric atmosphere was felt. It must also be stressed that the problem referred to by al-Tufi is not the problem referred to by Imam Malik. Imam Malik uses the theory of maslahah mursalah which although the issue is not contained in certain texts but is in line with the spirit (spirit) of the texts as a whole. This is different from al-Tufi which releases maslahah dependence on texts. Maslahah meant by al-Tufi only 
ends in reason alone. al-Tufi views that the texts are in conflict.

This "dangerous" statement needs to be clarified, because the author believes that al-Tufi does not intend to state that the verses of the Koran contradict each other. Perhaps what is meant by al-Tufi, is that there are verses that seem to contradict their birth but are not in fact contradictory. Speaking of maslahah, according to the author, maslahah is relative, for example a woman seizes an object. According to shariah law, the item must be returned to its owner. If lost, he must replace it. The problem is, how much does he have to replace the missing object? Some scholars argue that he replaced it according to the market price on the day of seizure. Some other scholars argue, he must replace it according to the price when he replaced it. Other scholars argue, replaced with the highest price of the two prices.

\section{Concluding Remarks}

b al-Tufi defines maslahah based on two things, both urf and shar'i, while in urf is السبب المؤدي إلي الصلاح و النفع: is a factor that leads to goodness and benefits. Like trading that brings profit. While according to shar'i maslahah, namely: السبب المؤدي إلي مقصود الثارع عبادة و عادة: is a causal factor that leads to the intention of lawmakers in matters of worship, or customs. maslahah is divided into two: those described by lawmakers for themselves, such as worship intended by lawmakers for the benefit of his creatures and the regulation of their affairs such as custom.

In building his mega project maslahah, al-Tufi relied on four main principles. Each principle is the main framework which is used by al-Tufi as the epistemological foundation, while the four principles referred to above are:

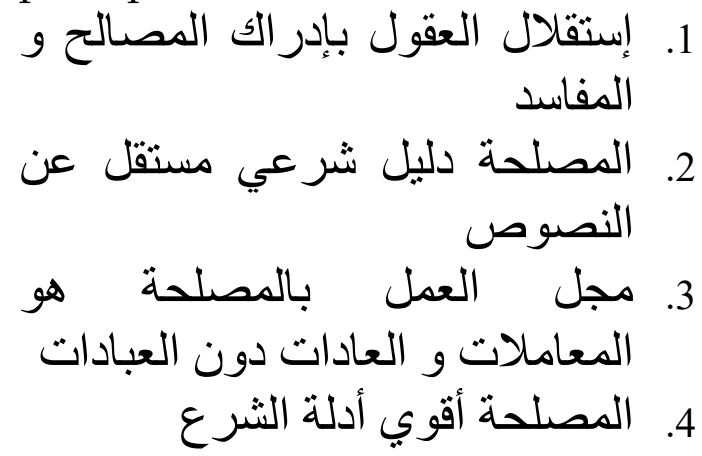

The relevance of al-Tufi's maslahah to the law is actually already evident in its epistemological footing number three being used as the foundation of the mega building of its maslahah project, which is clearly stated: مجل العمل بالمصلحة هو المعاملات دون العبادات ijtihad is only Muamalat (including business) not matters of worship. In the matter of worship at-Thufi let religious texts guide him.

\section{REFERENCES}

al-'Amiri, Abdillah M. Al-Husayn, Al-. 2004. T\}ufi Feflection of Traditional Muslim Juristic Source of Law and His Views On The Priority of Regard for Human Welfare as The Highest Legal Source or Prinsciple, terj. Abdul Basir, Jakarta: Gaya Media Pratama.

al-Anshari, Jamaluddin Muhammad bin Maukarram. t.th. Lisan al- 
'Arab, Cairo, Dar al-Misriyyah, juz. 3.

Al-Ghazali. 1983. al-Mustashfa fi Ilm al-Ushul, Jilid I, Beirut : Dar alKutub al-'Ilmiyyah.

Al-Jabiri, Muhammad Abed. 1991. Bunyah al-'Aql al-'Arabi, Beirut: al-Markaz al-Tsaqafi al-Arabi.

al-Kaylani. 2000. Abdurrahman Qawaid al-Maqasid 'inda Imam Syatibi, Damasyq: Dar al-Fikr.

al-Nadwi, Ahmad. 1420 H/2000 M. al-Qawaid al-Fiqhiyyah, Beirut: Dar al-Qalam.

Al-Syuyuthi, al-Asybah wa alNazha'ir, tahqiq: Muhammad al-Mu'tashim bi Allah alBaghdadi, Beirut: Dar al-Kitab al-'Arabi.

Anwar, Samsul. 2007. Hukum Perjanjian Syariah: Studi Tentang Akad Dalam Muamalat, Jakarta : Rajawali Press.

Departemen Agama Republik Indonesia. 2009. al-Quran dan Terjamah, Bandung, PT.Sigma Examedia Arkanleema.

Hafiny bin Nafis. t.t. Qawaid alLughah al-'Arabiyyah Li alTalamidz al-Madaris alSanawiyah, Surabaya: alHidayah.

Harun, Nasrun. 1997. Ushul Figh I, Jakarta: Logos Wacana Ilmu.

Hasan, Husein Hamid. 1991. Nazariyyah al-Maslahah fi al-figh al-Islami, Cairo, Dar alNahdhah al-'Arabiyyah.

Ibn Majah, Abu 'Abd Allah Muhammad bin Yazid alQawini. T.th. Sunan Ibn Majah, Dar al-Fikr, Beirut, Juz VI.
Ibn Majah, Sunan, Beirut: Dar al-Fikr, t.t., II, hlm. 784, hadis no 2340.

Irfan, Fuad.t.th. Munjid al-Tullah, Beirut, Dar al-Fikr.

Jazuli, A. 2000. Kaidah-Kaidah Hukum Islam Menyelesaikan MasalahMasalah Praktis, Jakarta: Pranada Media.

Makluf, Louis. 1986. al-Munjid fi alLughah wa al-'Alam, Beirut, Dar al-Masriq.

Malik. t.th. Muwatta', Mesir, Dar Ihya 1-Tsurats al-"rabi, juz. II.

Muslim, t.th. Sahih Muslim, "Kitab alBuyu'" Bab Tahrim al-Ihtikar fi

Amwal, Mesir: Isa al-Babi alHalabi wa Syurakah, Juz. II.

Sadzali, Munawir. 1995. Kontektualisasi Ajaran-ajaran Islam, Jakarta: Temprint.

Zayd, Mustafa. 1384/1964 M. alMaslahah fi at-Tasyri' al-Islami Najm al-Din Al-T\}ufi, edisi Kedua, Kairo: Dar al-Fikr al'Arabiya.

Zuhri, Saifuddin. 2008. dalam disertasinya Maslahah dan Implikasinya Sebagai Sumber Hukum Islam: Kajian Tentang Konsep Naj al-Din Al-T\}ufi (Ringksan Disertasi tidak diterbitkan). Yogyakarta, UIN Sunan Kalijaga, 2008. 